\title{
Corporate Social Responsibility and the Teaching of Management Accounting
}

\author{
Martin Kelly and Andrea Bather
}

Throughout most of the 20th century Management Accounting was developed on the premise that it should help managers to decide how best to maximise the short-term financial profits of their businesses. In the emergent Corporate Social Responsibility (CSR) business environment Post, Preston and Sachs ${ }^{I}$ ask, 'To whom and for what is the corporation responsible?'. In response to this question we examine publications describing recent changes in the corporate environment, and provide evidence of business decisions being made on the bases of: environmental, societal and other criteria, besides those relating to financial profitability. We question whether such changes in the corporate environment are being reflected in the way that Management Accounting is being taught in business schools today. We provide details of a final year course that we have developed at our university.

We examine the current state of society and the role of accounting in it. We hope that the need for a shift in the business decision-making environment becomes apparent to our readers as we discuss the United Nation's (UN) attempts to promote sustainable business practices. The arguments in favour of a shift to sustainable business development have received mixed responses; these are discussed. How businesses have been encouraged to accept the need for CSR, and employ various approaches in attempting to move toward sustainable development, is examined. The role of Accounting in supporting this development is explored. The need to produce Accounting graduates with the necessary attributes to fit into the evolving business environment is discussed. We describe a final year paper that we have developed for our Accounting students, which we believe will prepare them better for a business environment that requires innovative management systems.

\section{The Role of Accounting in Society}

In Society we collect and manage accounting information largely to assist us with our business decision-making. This purpose demands that we know what the objectives of our business decision-making are. Throughout most of the twentieth century most business people have been clear about this. The focus of business has been 'profitability', measured on a weekly, monthly, quarterly or annual basis. Longer term profitability has always been recognised as important, but not as important as the shorter term measurements that generate salaries, bonuses, promotion prospects and immediate respect.

In 1987 in New Zealand there were many listed companies that were reporting large financial profits. However, somehow, the base from which these profits were being generated was being depleted, without anyone appearing to notice. In the following few years over a quarter of the listed New Zealand companies perished because they could not meet their debts as they became due. We understand that New Zealand is not the only country to have had a 'stock market crash'. Indeed such crashes appear to happen periodically throughout the world.

One might believe that 'good' accounting practices should prevent such collapses but in New Zealand fewer than $20 \%$ of the companies that collapsed around 1987 had any audit qualifications on their last published Annual Financial Returns. ${ }^{2}$ More recently Enron, in the United States, demonstrated how close cooperation between leading professional accountants and unscrupulous business people could allow iniquitous business practices to proliferate without the public being aware of the outcomes until it was too late to deal with them satisfactorily.

\footnotetext{
${ }^{1}$ James Post, Lee Preston \& Sybille Sachs Redefining the Corporation Stanford University Press 2002 p 254

${ }^{2}$ Mike Pratt Going Concern Qualifications in Audit Reports of New Zealand Listed Companies which Failed after the 1987 Stock Exchange Crash, The British Accounting Association Conference (1993)
} 
What 'good' accounting practice is remains problematic. The figures shown in Figure 1 are taken from Smith \& Parr $^{3}$ and relate to companies in the United States. The figures are illustrative and we are confident that if a similar exercise were conducted on the largest 10 companies in the UK or Australasia today, the results would be similar.

\begin{tabular}{|l|l|l|l|l|l|}
\hline COMPAMY* & $\begin{array}{l}\text { MONETARY } \\
\text { ASSETS }\end{array}$ & $\begin{array}{l}\text { TANGIBLE } \\
\text { ASSETS }\end{array}$ & $\begin{array}{l}\text { OTHER } \\
\text { ASSETS } \\
\text { *.*. }\end{array}$ & $\begin{array}{l}\text { INTANGIELE } \\
\text { ASSETS*** }\end{array}$ & $\begin{array}{l}\text { REPORT } \\
\text { INTANG } \\
\text { ASSETS }\end{array}$ \\
\hline Microsoft & 10,159 & 1,505 & 260 & 523,449 & 0 \\
\hline Percentage & $1.9 \%$ & $0.3 \%$ & $0.0 \%$ & $97.8 \%$ & \\
\hline 3 M & 1,932 & 5,566 & 2,269 & 24,843 & 0 \\
\hline Percentage & $5.6 \%$ & $16.1 \%$ & $6.6 \%$ & $71.8 \%$ & \\
\hline Philip Moris & 3,851 & 12,335 & 9,780 & 96,629 & 17,600 \\
\hline Percentage & $3.1 \%$ & $10.1 \%$ & $8.0 \%$ & $78.8 \%$ & \\
\hline Nike & 1,829 & 1,153 & 276 & 10,323 & 464 \\
\hline Percentage & $13.5 \%$ & $8.5 \%$ & $2.0 \%$ & $76.0 \%$ & \\
\hline Walt Disney & 1,850 & 12,852 & 3,382 & 44,030 & 15,800 \\
\hline Percentage & $3.0 \%$ & $20.7 \%$ & $5.4 \%$ & $70.9 \%$ & \\
\hline
\end{tabular}

* All figures are in US \$million and relate to the financial year ending in 1998

** Net working capital

*** Fixed assets

**** Typically investments in uncontrolled subsidiaries and joint ventures

***** Intangible assets (and intellectual property) calculated by deducting columns 1-3

from market value, which is calculated as: share price + outstanding long-term debt.

Figure I

Thus, for example, while the market value of Microsoft was known to be $M \$ 535,373$, its value appearing in its accounts, prepared according to Generally Accepted Accounting Principles (GAAP), was $M \$ 11,924(M \$ 260+1,505+10,159)$; that is only $2.2 \%$ of its market value.

The figures shown demonstrate that when the financial accounts of listed companies are prepared according to GAAP, it is probable that the value of the company will be understated by more than half because the accounts do not show the values of any so-called intangible assets'. Thus managers must recognise that reported accounting information may be partial and not reveal the known financial 'facts'. Reported financial results may not be an adequate measure of a business's performance.

Furthermore the effect of humankind's business activities on the planet during the past hundred years has been disastrous. In the 1980s, the United Nations (UN) realised the problems that business decisions were creating in the world (in particular with regard to the

${ }^{3}$ Gordon Smith \& Russell Parr Valuation of Intellectual Property and Intangible Assets (Third edition), New York: John Wiley and Sons, Lrd 2000 
environment) and it set up the Brundtland Commission to report on these problems. The Brundtland Commission reported in $1987^{4}$ and its report provided what has probably become the most widely quoted description of 'Sustainable Development':

Humanity has the ability to make development sustainable - to ensure that it meets the needs of the present without compromising the ability of future generations to meet their own needs.

The effects of the economic paradigm on the world society were publicised by the UN in the 1980 s and the first Earth Summit was organised, to address the UN's concerns, in Rio de Janeiro in 1992.

A World Summit on Sustainable Development in Johannesburg in 2002 was used to discuss the progress that had been made in addressing the issues of sustainability that were identified for the 1992 conference in Rio. For the Johannesburg conference the UN asked a team of scientists to produce a report detailing the state of the planet from a sustainability perspective. A report was produced by Doering et al. ${ }^{5}$ Brief excerpts from the report are reproduced here:

- Nearly 26,000 plant species, more than 1,100 mammals and 1200 birds, 700 freshwater fish, and hundreds of reptiles and amphibians are threatened with extinction

- The world is $78 \%$ poor, $11 \%$ middle income and $11 \%$ rich

- More than half the world's citizens have never used a telephone, $7 \%$ have access to a personal computer and only $4 \%$ have access to the Internet

The UN also commissioned another report from leading scientists in 2001; this was released in 2005 as The Millennium Ecosystern Assessment Synthesis Report. ${ }^{6}$ It provides a further insight into the state of the planet at the start of this century. Again a brief excerpt is reproduced here:

First, approximately $60 \%$ ( 15 out of 24) of the ecosystem services examined during the Millennium Ecosystem Assessment are being degraded or used unsustainably, including fresh water, capture fisheries, air and water purification, and the regulation of regional and local climate, natural hazards, and pests. The full costs of the loss and degradation of these ecosystem services are difficult to measure, but the available evidence demonstrates that they are substantial and growing. Many ecosystem services have been degraded as a consequence of actions taken to increase the supply of other services, such as food. These tradeoffs often shift the costs of degradation from one group of people to another or defer costs to future generations.

These two reports should cause concern to all citizens.

\section{Responses to the State of the Planet}

There is a growing body of people who are concerned about the state of the planet. However, response to the sustainability problem in the global arena has been mixed.:

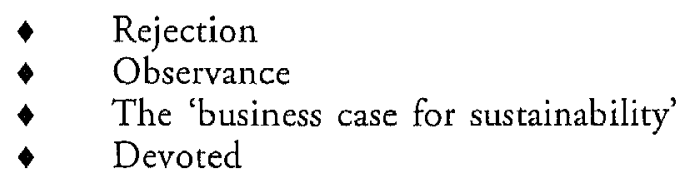

${ }^{4}$ Brundtland Commission Our Common Future The World Commission on Environment and Development, Oxford University Press 1987

${ }^{5}$ Don Doering, Amy Cassara, Christian Layke, Janet Ranganathan, Carmen Revenga, Dan Tunstall, and Wendy Vanasselt Tomorrow's Markets World Resources Institute, United Nations Environment Programme and World Business Council for Sustainable Development 2002. Bulleted points are drawn from pp 33, 13 and 45 respectively.

${ }^{6}$ United Nations Millennium Ecosystem Assessment Synthesis Report New York, Aurhor 2005 
Some people reject the message, professing to believe that there is no real problem. They believe the appearance of a problem is caused by the frantic ravings of 'Green' activists and others with over-developed social consciences.

A second group of managers is starting to recognise that something is changing in society as the sustainability message gathers momentum, some embryonic laws concerning sustainable business developments are drafted, and schedules of 'good practices' are developed. This group appears willing to comply with what is imposed on, and perhaps requested of, business managers but it has little enthusiasm for the cause.

A third group has recognised a business case for developing and publicising a sustainable business plan. It sees an opportunity in telling others in society that firms care about: the natural environment, social justice and the world generally. By doing this its members believe they will attract:

- Socially conscious investors, who will provide capital when required

- The 'best' of staff who wish to work for companies they can be proud to work for

- Customers who are happy to support an organisation that appears committed to sustainable development

- Trading partners who will happily trade with an organisation that appears committed to sustainable development

- An excellent reputation in the community at large

A fourth group believes that it has no alternative but to adopt a commitment to sustainable business practices because if it does not, humankind will perish. Furthermore, its members' devotion to the sustainability cause makes them feel good about how they are living their lives.

We suspect that membership of the fourth group was very small as recently as ten years ago. However, with the publication of convincing arguments illustrating the need for sustainable business practices developed at the UN and elsewhere, and with the publicity that has been generated by NGOs and other activists such as Al Gore (the US presidential candidate who produced the film, 'An Inconvenient Truth' dealing with 'global warming'), we believe membership of this group has grown considerably.

We believe there are now few large organisations whose managers remain in Group One. Perhaps the majority of managers in large companies belong to Group Three. They may have got there, and remain there, because of the beliefs of others in society. Even if they do not believe that the world is in danger from the depletion of its assets, their decisions are made in an environment where others, who believe in the need for sustainability, observe their actions, and evaluate their business's performance from that perspective. Thus they cannot afford to dismiss the sustainability message; it has become closely related to their business's profitability in our changing society.

\section{How to Take Up the Sustainability Cause}

Until around a decade ago it was difficult to find any 'tools' to use, if one became interested in implementing a sustainable approach to business. However, there has been a number of tools developed recently, and probably more and better ones will arrive soon. We will mention a few here:

\footnotetext{
- Elkington's Triple Bottom Line

- Kaplan's Balanced Scorecard

- The Global Reporting Initiative

- Corporate Social Responsibility (CSR)
} 
Corporate Social Responsibility and the Teaching of Management Accounting

Elkington ${ }^{7}$ has introduced his Triple Bottom Line approach to the reporting of business performance. He suggests that besides reporting their financial profits each year, businesses should also report their performance in the areas of environmental performance and societal performance.

$\mathrm{Kaplan}^{8}$ has introduced the Balanced Scorecard, to encourage a broader reporting platform. It attempts to push managers to think beyond the reported short-term profitability of theit organisations and consider: customer satisfaction, organisational learning and business processes.

The Global Reporting Initiative (GRI) was created by the Not-for-Profit organisation CERES, in 1997-1998, which was joined in 1999 by the United Nations Environmental Program (UNEP). It is now an independent programme. The GRI continues to develop. It suggests the matters businesses should report on, outside their financial performances. Additionally it has specifically suggested what details it might be useful for specific industries to report on, for example: pharmaceuticals, telecoms and tobacco.

All of these approaches to providing information for better decision making are, we argue, examples of a move by corporations to take on greater social responsibility for their decision making. Unfortunately though, students in many business schools are not being properly prepared for this new business environment.

\section{The Role of Accountants in the New Social Environment}

Kelly and Pratt ${ }^{2}$ summarise the history of management accounting, noting that although the practices of management accounting can be traced back to the nineteenth century, the first known textbook emerged in 1950 , written by Vatter. ${ }^{10}$ Vatter argued that 'management accounting had the purpose of supporting managers, not of reporting to owners', a change from the predominant role of the financial accountants. Kelly and Pratt observed that the rise of management accounting out of a neo-classical economic paradigm has influenced the training of management accountants. Their work investigated the development of one commonly used management accounting textbook; ${ }^{11}$ this investigation is continued below to find out how management accounting education might have changed with the emergence of the CSR decision model. A 1988 survey by Kelly and Pratt, led them to conclude that:

...the contents of textbooks had waried little, both in contents and approach, from textbooks in use 30 years earlier, despire the many articles criticizing conventional wisdom which had appeared in recent journals. The then current textbooks did not question holistically the direction the discipline was taking; rather they presented a well-defined body of knowledge which was changing slowly at its edges. We suggested that decision-makers, who take a broader perspective, were becoming less interested in the management accountant's narrow but often complex ways of approaching decisions.$^{12}$

If the role of the management accountant is to assist managers in the realisation of goals, then two questions must be answered:

\footnotetext{
${ }^{7}$ John Elkington Cannibals with forks: The Triple Bottom Line of 21st Century Business Gabriola Island BC, New Society Publishers 1998

${ }^{8}$ Robert Kaplan \& David Norton The Balanced Scorecard: Translating Strategy into Action London, Harvard Business School Publishing 1996

${ }^{9}$ Martin Kelly \& Mike Pratt 'Management accounting texts in New Zealand: The need for a paradigm shift' Accounting Education 3 no 4 (1994) pp313-329

${ }^{10}$ William Vatter Managerial Accounting Englewood Cliffs Prentice Hall 1950 quotation p 316

${ }^{11}$ Charles Horngren Cost Accounting: A Managerial Emphasis Englewood Cliffs Prentice Hall 1962

${ }^{12}$ Kelly and Pratt loc cit 1994 p 314
} 
1 What goal(s) are to be achieved? 'Why' is management accounting necessary?

2 What are the appropriate theories and techniques to learn in order to provide assistance in the achievement of those chosen goals? 'What' theories and techniques need to be learned?'13

The 'theories and techniques' taught may need to be expanded to include a more holistic approach to the role of management accounting as discussed above. O'Dwyer ${ }^{14}$ discusses the role of accountants in SEAAR - social and ethical accounting, auditing and reporting. He notes that the large accounting firms are making significant income from involvement with CSR types of accounting, making it arguably mainstream. In discussing AA100013 ${ }^{15}$ he states:

The standard emphasises an association between accountability to stakeholders and corporate financial performance, thereby reflecting, to some extent, the strategic stakeholder management focus of instrumental stakeholder theory... This emphasis mirrors many of the recent efforts to engage business in SEAAR, where its adoption is advanced as a win-win type scenario enhancing corporate financial performance (particularly in the long term) through increasing accountability to stakeholders... ${ }^{16}$

O'Dwyer puts the role of management accountants as central to the implementation of such strategies. Accountants create management information systems, which provide information that is necessary to 'produce social accounts'. ${ }^{17} \mathrm{He}$ discusses the role of accountants in the auditing of social accounts, noting that technically they are well-placed to take on that task, provided the concept of independence is maintained. He suggests that given accounting firms such as KPMG (UK) ${ }^{18}$ are fully engaged with social accounting and auditing, such practices need to be addressed in the training of accountants.

The textbook analysed by Kelly and Pratt (Horngren, first edition, 1962) was authored by Horngren alone until the 6th edition. Foster became a co-author for the 7th edition, and was joined by Datar for the 8 th edition. It is now in its 12 th edition ${ }^{19}$ and is still in general use as an introductory text in management accounting in many universities, especially in the U.S. It appears to us that its focus has changed little in recent years, despite the emergence of CSR. The twelfth edition informs students that:

The key to a company's success lies in creating value for customers while distinguishing itself from competitors. Identifying how a company will get this done is what strategy is all about. Strategy specifies how an organisation matches its own capabilities with the opportunities in the marketplace to accomplish its objectives. Businesses follow one of two broad strategies. Some companies... [provide] quality products or services at low prices. Other companies generate their profits and growth on the basis of their ability to offer unique products or services that are often priced higher than...their competitors. ${ }^{20}$

Thus Horngren et al no longer state outright that profit maximisation is the goal of the company, but what the 'objectives' of an organisation are (or should be) are not clearly discussed. It is not until the final chapter that the possibility of a company being socially aware when making decisions is discussed; a section on corporate codes of conduct and ethics has been introduced:

\footnotetext{
${ }^{13}$ loc cit $\mathrm{p} 315$

${ }^{14}$ Brendan O'Dwyer 'The Legitimacy of Accountants' Participation in Social and Ethical Accounting, Auditing and Reporting' Business Ethics: A European Review 10 no 1 (2001) pp 27-39

${ }^{15}$ An accountability standard of the Institute of Social and Ethical AccountAbility

${ }^{16}$ loc cit pp $28-29$

${ }^{17}$ loc cit $\mathrm{p} 30$

${ }^{18} \mathrm{KPMG}$ (UK) is estimated to have earned 20 million pounds from its social accounting division between 1999 and 2002 (Watts, 1999, cited in O'Dwyer, 2001). But as O'D wyer states, 'The provision of this service is tied in with KPMG's perceived core competencies. Emphasis focuses on addressing the full range of business risks including criticism from the media and pressure groups, which is perceived as threatening value creation...' (p. 29).

${ }^{19}$ Charles Horngren, Srikant Datar and George Foster Cost Accounting: A Managerial Emphasis (12 ${ }^{\text {th }}$ ed) Pearson Prentice Hall 2006

${ }^{20}$ Charles Horngren, Srikant Datar and George Foster op cit $\mathrm{p} 3$
} 
Measuring and rewarding managers for achieving critical performance variables is an important driver of corporate performance. But these diagnostic control systems must be counterbalanced by the other levers of control - boundary systems [ie codes of business conduct], belief systems [ie mission, purpose, and core values of a company], and interactive control systems - to ensure that proper business ethics, inspirational values, and attention to future threats and opportunities are not sacrificed while achieving business results. ${ }^{21}$

We believe such statements in a contemporary Management Accounting text represent too little coverage of a most important topic, far too late in the text. Continual descriptions and explanations of cost accounting techniques are found from the first to the last chapters. According to the text, the 'enriched content' of the 12th edition includes:

- Increased coverage of strategy and strategic uses of cost information;

- A framework for cost accounting and cost management; increased coverage of the balanced scorecard;

- Activity based costing presented in a single chapter;

- Increased discussion of decision uses of cost accounting information;

- Systematic incorporation of new and evolving management thinking including activitybased management,

- Integrated approach to variance analysis and levers of control;

- Incorporating advances in technology into coverage of topics (preface p.xxii).

In terms of management accounting techniques evolving within the traditional economic framework the text may be up-to-date. In other respects, we argue, it is not.

However, some progress outside the economic framework has been made. The concept of ethics is presented in a much more authoritative manner. The preface to the text makes reference to the well-known corporate collapses of the early 21 st century, and explains the resulting inclusion in each chapter of a 'values and behaviour' box, in which students can view examples of companies interacting with professional standards. Such examples illustrate where management accountants did not live up to professional standards, or advise students when to withstand pressure from management to breach ethical standards in particular situations. Examples, problems and collaborative learning at the end of each chapter also incorporate ethical questions. This content however is formulated to direct the mind of the student to rules based ethical behaviours; 'integrity' is defined in accordance with the codes of conduct of professional bodies. Students are not encouraged to understand how ethical behaviour might evolve, independently of any prescribed regulations, within an alternative business paradigm outside of the economic paradigm. There is no reference in the index of the text to stakeholders or CSR, although one page containing information on socially responsible companies is indexed. The concept of corporate social responsibility is not explained, except by implication from the examples provided.

It appears that the latest edition of Horngren's text has been unable to completely ignore the issues of: morality, business ethics and CSR. However, its coverage in this area appears minimal, inadequate and to be grudgingly incorporated into a text concentrating on economic prerogatives, although the global consequences of adopting such prerogatives are now well documented. Santos and Vega ${ }^{21}$ provides an analysis of finance textbooks used in United States Business Schools. It analyses 14 texts and reports:

that almost every textbook uniformly teaches or emphasises the goal of the firm as unconstrained shareholder wealth maximisation, but offers inadequate discussion of business ethics and corporate governance... Finance students are rarely introduced to competing ideas in corporate governance, such as stakeholder theory, the commitment to act in consonance with the best interests of all stakeholders, including shareholders.

\footnotetext{
${ }^{21}$ Charles Horngren, Srikant Datar and George Foster op cit $\mathrm{p} 813$

${ }^{21}$ Michael Santos \& Gina Vegas (2006) 'Both Sides of the Story: Teaching a Constrained Shareholder Wealth Maximization Goal in Finance. Proceedings from the $5^{\text {th }}$ Global Conference on Business and Economics. Cambridge University, UK (July 6-8 2006) quotation p 2
} 
Santos and Vega recommend teaching, 'that shareholder wealth maximisation should not be achieved at the expense of stakeholders such as employees, environment, local community, creditors, and similar entities...'.22 In many contemporary business textbooks, the purpose of business remains fundamentally to make money for shareholders in the short-term. As Santos and Vega conclude, textbooks should improve upon their current offerings... all competing theories in corporate governance ${ }^{23}$ should be presented so that students can make informed managerial decisions'. ${ }^{24}$ Textbooks and course curricula should reflect the changing manner in which business is conducted in our contemporary society.

\section{The 'Organisations \& Society' (O\&S) Course at Waikato Management School}

The O\&S course is a final year course for Accounting majors. Those taking it will have studied how to consolidate group sets of accounts, and audit them. They will have learned to solve linear programming problems so that scarce resources can best be deployed to maximise outputs. They will have learned about the time value of money and how to perform discounted cash flow calculations to ensure that projects that provide investors with the best financial returns can be identified. We are not opposed to such learning taking place amongst students who have chosen to study to become accountants. However, we were worried that many graduates were leaving university without gaining a proper understanding of the role of Accounting in organisations and society and the ethical responsibilities that it should involve. Therefore, the course objectives of the O\&S course are unusual for an Accounting course:

\section{Desired developments in the students}

Citizenship: their ability to be aware of their own emotional, spiritual and societal values as well as their cognitive identities. Their courage to promote change.

Knowledge of the literature which considers Accounting as a social phenomenon.

Self-understanding, self-awareness, self-confidence and intellectual independence.

The ability to self motivate and self organise.

The ability to provide arguments and listen, rather than to 'debate'.

The wish to strive for the best solutions, rather than to seek opportunistic compromises.

A 'professional' approach to life in preparation for the workforce.

A wish to question and evaluate, throughout life.

Knowledge of their role, and the role of management, in society.

10

Knowledge of how to learn (this will be a redevelopment, as babies are born with it).

Figure 2

The class extends over twelve weeks and there are four hours of class contact each week, making a total of 48 hours class contact. The four hours are taken as two, two-hour slots. There is a two week break after the sixth week of the class. The first two weeks of the class are used to introduce the students to background information to the class. Students are introduced briefly to:

- Modernism and Post Modernism

- Critical theory and the Frankfurt School, plus Habermas

- A critique of economic theory

- Dialectical enquiry, from Zeno to Hegel, plus Mitroff and Mason (1981)25

- Jung's psychological writings: sensation, thinking, feeling, intuition, plus introverts and extroverts

\footnotetext{
${ }^{22}$ Santos and Vega op cit $\mathrm{p} 2$

${ }^{23}$ The way a corporation is organised to achieve its purposes. It involves goal setting, transparency and accountability. It may embrace broad societal responsibilities rather than recognising only responsibilities owed to the shareholders.

${ }^{24}$ Santos and Vega op cit $\mathrm{p} 5$

${ }^{25}$ Ian Mitroff \& Richard Mason Creating a Dialectic Social Science Reidel, Dordrecht Holland 1981
} 
- The Burrell and Morgan (1979) framework ${ }^{26}$

- Existentialism, through Pauchant (1995) ${ }^{27}$

- Corporate governance, CSR, stakeholder management and sustainability

The students are told that the course attempts to be student-centred and, within limits, they are encouraged to journey (and take class members with them) to areas of interest for them. The need to develop the ability to listen to others is highlighted.

In the second week students are asked to consider the current place of Accounting in society with reference to the arguments contained in the earlier parts of this paper. They are asked to consider why they came to university, what they wanted to achieve from the experience and how well they have been satisfied. They are asked to consider how they might best develop for their coming role in society, and what they will be hoping to provide to the business world after their graduation. They are asked to read Craig, R and Amernis, J Accountability of accounting educators and the rhythm of the university: resistance strategies for postmodern blues ${ }^{2 \mathrm{~B}}$ and turn up to class ready to discuss it; the results are always worthwhile.

There are between 50 and 80 students in the class each year. After the first two weeks the class is split into tutorial groups for one of the two hour sessions each week, and various modes of learning are employed. Each tutorial group contains between 10 and 20 students. Each week there is one two-hour 'lecture' session and one two-hour tutorial. Five outside visitors are arranged for the lecture sessions and they visit every other week. These are always 'successful' people. They are asked to speak for about 50 minutes and address the following question:

- How they achieved their success after completion of their education?

- How they define success?

- Any mistakes they feel, in retrospect, they may have made in developing their careers?

- What they do on a 'typical' day at work?

- What the most stressful part of their current job is ?

- How they achieve a work/life balance?

Following the visitor's address to the students, the students have around one hour to ask questions of the visitor. The students enjoy these sessions, which give them a chance to learn about the business world today. The visitors each year include both a person from one of the Big4 accounting firms and someone from a small local firm who has been relatively successful. Regular visitors to the class have been:

- The CEO of Ernst \& Young New Zealand

- The CEO of New Zealand Chamber of Commerce

- The editor of the newspaper with the highest local circulation

- The CEO of the large regional hospital

We have asked over 20 business people to visit the class and have never had anyone refuse us. All of the visitors that we have invited have enjoyed talking with the class; without exception they have offered to return to speak with students in subsequent years. The visitors are not paid and half of them travel over 100 kilometres to come to the university. We have found this commitment surprising and the students' appreciation to be excellent. In the remaining five weeks of lectures we cover selected topics, which include:

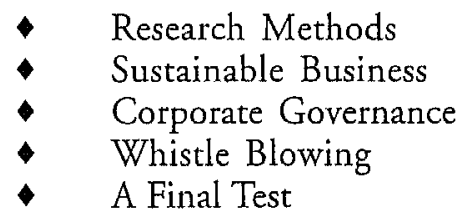

- Research Methods

- Sustainable Business

- Corporate Governance

- Whistle Blowing

- A Final Test

${ }^{26}$ Gibson Burrell \& Gareth Morgan Social paradigms and organizational analysis Heinemann, London 1979

${ }^{27}$ Thierry Pauchant In Search of Meaning: Managing for the Health of Our Organizations, Our Communities and the Natural World Josey-Bass, San Francisco 1995

${ }^{28}$ Russell Craig \& Joel Amernis 'Accountability of Accounting Educators and the Rhythm of the University: Resistance Strategies for Postmodern Blues' Accounting Education 11 No 2 (2002) pp. 121-171. 
All of the lectures are delivered from a critical perspective and questions are posed to the class. The aim is to encourage students to become critically aware of the business society that they will be joining shortly.

For each of the 10 tutorial sessions students are asked to read an article selected by us and hand in a précis of it at tutorial. The articles vary each year depending on which articles have captured our interest but the articles will generally cover such topics as:

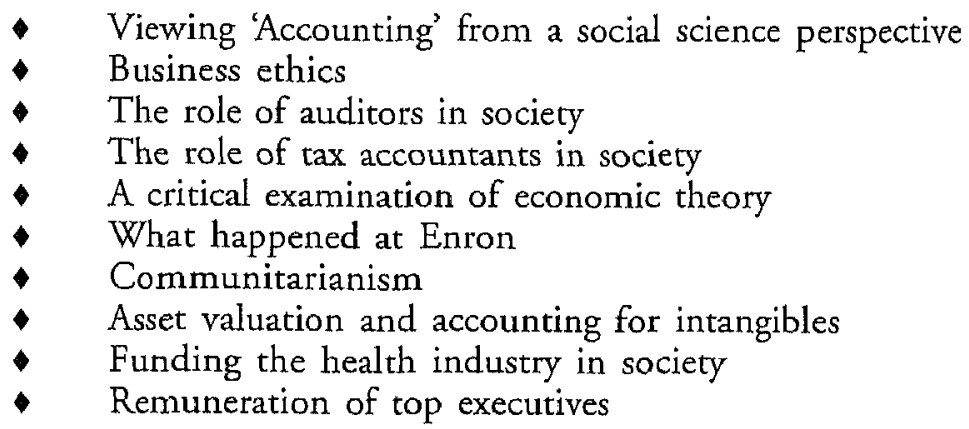

The students receive $15 \%$ of their final grade for doing nothing initially, but if they fail to provide us with a précis any week, without adequate explanation, they lose one percentage point. In class a student is asked to present a paper of his/her own choosing in the same area as the set reading, and then to lead discussion in the given area. The student is asked to engage the class for around 30 minutes. In some weeks we have two students providing such presentations because we have more than 10 students in most tutorial classes. Some of these presentations are excellent but unfortunately too many are not well done, and the class tutor must supplement them.

When a student presents s/he is graded by everyone else in the class (excluding the tutor). The grade counts up to $10 \%$ towards the student's final grade for the class. Students are schooled in how to provide 'good' feedback in the first week of the course. They must provide a grade for the presentation plus comments, which should help the presenter to improve his/ her future presentation performances. The feedback is provided electronically after the class. Students are given 48 hours to provide feedback; if they do not provide feedback they lose one percentage grade point. The presenter receives the average score awarded by the classmates. The feedback is received anonymously because we found that when the feedback source was known to presenters, we experienced examples of revenge grading in the later weeks of the class. This is unfortunate but it forced us to adopt the anonymous feedback option. Altogether the students have up to $25 \%$ of their final grade determined by their work in the tutorial discussions.

For the remainder of the tutorial session students are given time to work on their Small Group Projects (SGP). The SGP are reports that address chosen contentious issues in society. They are produced by groups of 3-5 students (students' choice). In the first week of the course students are asked to identify an issue in society that is contentious and which they have passionate views about. Examples of such issues have been:

- Allowing genetic engineering in New Zealand

- The need for nuclear power generation in New Zealand

- Gold mining in New Zealand

- The introduction of a capital gains tax in New Zealand (it has none)

- Integration of mentally disabled people from hospitals into the community

When students bring these issues to class they are listed on the screen and those issues that have different individuals passionately committed to supporting both sides of the arguments, are identified as areas suitable for the SGP. The SGP is a dialectic enquiry where the thesis individual(s) are charged with providing the best arguments possible, with supporting literature, for their opening position. The antithesis individual(s) are similarly charged. The group is then charged to work towards a synthesis by the end of the semester. Initially 
students were expected to undertake primary research in the area of their SGP and interview relevant people in the community. Unfortunately our university's ethical research committee has now outlawed such research and the students must rely on secondary research to support their opening arguments. Students are expected not to keep seeking supporting literature after the first couple of weeks of their SGP. Thereafter progress in reaching a synthesis is to be made by carefully listening to their opponents' arguments and responding appropriately.

The final report is graded after the end of the semester and counts up to $25 \%$ towards the students' final grades. It is graded on: overall interest, strength of opening arguments, evidence of listening and responding, progress towards a synthesis and evidence of a growth in overall understanding in the area.

Although the students are provided with some time in tutorials each week to develop their SGPs, they will normally have to arrange meetings out of class to help progress their projects. Students also often have electronic conferences through emails to help them make progress. As always some of the SGP reports are excellent, while others are disappointing and evidence that the dialectic approach to decision making has not been properly understood; we continue to work to address this problem.

The final test for the course is provided in the two-hour lecture slot in the final week of the course. It counts for up to $25 \%$ towards the students' final grade for the course. We reserve the right to ask them about any issues that have been discussed on the course. We promise that one area that will be examined is the class visitor sessions; this ensures that attendance at these sessions throughout the semester is high. Examples of test questions that have been used are in the Figure below.

The visitor sessions in class are provided to allow you to learn about contemporary life in the business world and help you to plan your career development. Identify the visitor session that you found the most helpful and explain why.

(15 marks)

Explain what is meant by the following terms and how they fit with, or might influence, management practices (or management education) in the contemporary world:
a) Postmodernism
b) Existentialism
$(2 \times 10$ marks $)$

Explain the difference between a synthesis and a compromise; explain which sort of outcome you consider is best to work towards when there is a difference of opinions.

(10 marks)

Discuss the following quotation taken from Rogers (1983, p. 120): 'The only man (sic) who is educated is the man who has learned how to adapt and change; the man who has realised that no knowledge is secure, that only the process of seeking knowledge gives a basis for security. ${ }^{29}$

(10 marks)

Explain what 'corporate governance' involves. Describe some problems that have occurred, and suggest how the process might be managed to address these problems.

(20 marks)

Overall do you believe your education at the Waikato Management School has prepared you well to build a career in society?

(25 marks)

Figure 3

The final $25 \%$ of the students' grades are earned from a 3000 word essay that must be submitted at the end of the sixth week of the course. The title of the essay varies each year but is always on an issue that is being given attention in the academic press. The students are informed of the title of the essay in the first week of the course. In 2007 the essay title was, "Should social justice be an element in management education?"

${ }^{29}$ Rogers, C Freedom to learn for the 80's Columbus: Bell and Howell 1983 p 120 


\section{Conclusion}

We are pleased with the course that we have developed; it continues to develop as we learn from our experiences each year. The course has been offered for around 10 years now. When it was first offered it was unpopular with around two thirds of the students that participated. We estimate that now around two thirds of the class appreciate the course experience. There are three major types of feedback that we receive and an example of each is shown below:

- As students complete the course (unfavourable), 'This course was totally inappropriate for business students; if I wanted to learn about philosophy I would have taken a philosophy course.'

- As students complete the course (favourable): 'A great course, all students should receive it in first year (not in their final year), they would then get so much more out of their other university courses.'

- Former students (we don't hear from all those who did not enjoy the course): 'My best course at university, I learned to listen, question and argue; I developed as a person.'

We believe there are two explanations for the better reception the course has received in recent years. Firstly, we have listened to students' complaints/suggestions and removed/adapted the parts of the course, which caused the most annoyance to students. Secondly, the environment in which the students meet the course has changed considerably. As recently as 10 years ago students at our university were being taught in many classes that the only purpose of business in society is to maximise the wealth of shareholders. Today most of our colleagues have ceased to promote such a message. At our university the age of education for sustainable business practices has arrived.

\section{Martin Kelly}

Martin was an accountant with British Gas before immigrating to New Zealand in 1987 and becoming a university lecturer. He is currently Joint Chairperson of the Department of Accounting at Waikato Management School. On starting to teach Martin had to think carefully about the content of his classes. What should academics tell students about business decision making? He has continued to reflect on this question and develop his responses to it.

Martin is a Chartered Accountant and a Fellow of the Association of Chartered Certified Accountants. He holds a $\mathrm{PhD}$ in Accounting and has over 100 publications to his name.

\section{Andrea Bather}

Andrea Bather is a Senior Tutor in Commercial Law with the Accounting Department at the Waikato Management School (WMS), Hamilton, New Zealand, and teaches corporate and commercial law while also being involved with the accounting papers. She is particularly interested in the wide range of issues covered by Corporate Governance and Corporate Social Responsibility, and her publications deal with matters under these headings. Andrea is currently preparing to enrol in a PhD at WMS looking at Corporate Governance in New Zealand and the UK. She holds a current practising certificate. 